\title{
Determining Factors That Affect the Quality of Process and Training Results of Non-formal PAUD Educators in Indonesia
}

\author{
Joko Sutarto, Departmen of Nonformal Education, Faculty of Education, Universitas Negeri Semarang, \\ Indonesia, jokotarto@mail.unnes.ac.id \\ Sungkowo Edy Mulyono, Departmen of Nonformal Education, Faculty of Education, Universitas Negeri \\ Semarang, Indonesia, sungkowo.edy@mail.unnes.ac.id \\ Imam Shofwan, Departmen of Nonformal Education, Faculty of Education, Universitas Negeri Semarang, \\ Indonesia, ishofwan@mail.unnes.ac.id
}

\begin{abstract}
This study aims to analyze the determinant of the quality of the process and the results of training of paud non-formal educators in central JavaProvince, Indonesia. Determinant factors include exogenous variables (predisposing factor, leadership, training climate, cost, infrastructure, training planning, training implementation. While endogenous variables are the use of e-training and training results. Research method using quantitative approach, survey method in the form of correlational by analyzing confirmatori factors. Sampling techniques are randomly proportional based on training classes. The number of research samples was determined by Solvin formula, amounting to 183 respondents of Non-formal PAUD educators in Central Java who participated in e-training-based training. Data collection using questionnaire with likert scale, data analysis with structuralequation modeling measurement (SEM). The results showed that exogenous variables against the highest training result variables and strong palig influence is the training planning variable of 0.393 . While the variables without influence on training results with the existence of e-training are trends, leadership, and training factors.
\end{abstract}

Keywords: quality of training process, training results, use of e-training

Received: 04.12.2020 Accepted: 19.01.2021 $\quad$ Published: 03.02.2021

\section{Introduction}

The era of globalization shown towards digital technology, demands the availability of competent human resources in order to keep up with it. The development of digital technology can lead to the formation of primitive and isolated human resources if avoided. Fulfillment of competent human resources to keep abreast of digital technology can be done through education, so there is a good concern by a country. Human resources are one of the fundamental aspects in running the government, maintaining the sustainability of life and maintaining the development of the country in order to achieve the predicate as a developed country. The next generation of qualified nations can be formed if the resources that run the education master the technology according to the development of the era. The sophistication of technology utilized by educational actors must certainly be supported by the quality of human resources that are capable in carrying outwork.

Many realities in the field show that the quality of Indonesian people as potential resources is far from expected. This is because of the low quality of education in Indonesia. Some cases that describe these conditions include (1) low education services in Indonesian, (2) quality of low education in Indonesian, (3) low quality higher education in Indonesian, (4) low Indonesian literacy capabilities(Widodo, 2016) children. Practically this fact shows that education in Indonesia today is experiencing many challenges and problems. Automatically this condition has a direct impact with graduates produced due to the low quality of education, graduate quality is also low. The low quality of education is the main obstacle for the Indonesian nation to be able to step into the life of the 21 st century.

Based on Permendiknas No. 58 Year 2009, early childhood educators are professionals who are responsible for planning, implementing the learning process and evaluating the learning outcomes and carrying out, parenting and protection of students. Law(Thakur \& Natale, 2009)No.14 of 2005 explains that the competencies of teachers or educators those mentioned in Article 8 include pedagogical competences, personality competences, social competences and professional competences obtained through professional education. As an agent in education, teachers are required to be professional by fulfilling these four competencies.(Republik Indonesia, 2005)

Based on the strategic role of PAUD educators, in the framework of human resources development the government seeks to improve the quality of performance of PAUD educators that leads to dignified 
professionalism as a profession. Education and training activities towards professionalism in order to expand access and improve the quality of PAUD services for the community continue to be carried out in the last four years since the enactment of Permendiknas number 16-year 2007. About the standard of educational qualifications and the process of improving quality and competence of PAUD educators. The policy is very important as the basis for regulate activities to improving the quality of non-formal education. However, the implementation of the policy is inseparable from the responsibility of the government, namely under the early childhood education development center and community education which is a nonformal educational institution.

Early childhood education development center and community education of Central Java (PPPAUD and DIKMAS Central Java) is the The implementation of technical unit in the Ministry of Education and Culture in the field of early childhood education for development and community education below and is responsible for the director the general of childhood early education and general of education (Shofwan et al., 2019). PP-PAUD and DIKMAS Central Java have the task of carrying out the development of education model and quality. Aninstitution must have a clear policy statement on quality. Quality policy is a statement of commitment delivered by the institution. (Creswell, 2013)

Quality policy is in the quality plan. Human resource development requires an institutional plan and needs analysis process, and it also requires a monitoring and evaluation system that is useful for measuring the effectiveness of short-term and long-term training programs. The criteria of human resource investment standards can be used as a reference list to determine the quality standards that must be met. Sendangkan in his research analyzed the role of competence (training) to the performance of the workforce (Setyowati, 2010). Its findings suggest knowledge and skills will direct behaviour; and behavior produces performance. Education for educators is the process of teaching knowledge and skills and certain attitudes (Djibu et al., 2019) so, that education is more skilled and able to carry out its responsibilities better, in accordance with standards.

This can be exceeded by activities and training. Training usually refers to the development of work skills that can be used immediately. Based on several research findings, study research aims for analyze the determinant of the quality of the process and the results of non-formal PAUD educators in Central Java, Indonesia.

\section{Research Methodology Study Contexts and Procedures}

The study reseacrh aims to the analyze factors that have causal relationships between complex variables and are not observed to directly affect the quality of the process and the results of training of non-formal paud educators in Central Java. The research methodology adopted quantitatively assessed the strength of the relationship between these variables and its indicators, while the research approach adopted was a deductive approach because this research was quantitative and aimed at testing a series of theoretical hypotheses. Therefore, achieving the (Thornberg, 2012)(Weston \& Gore, 2006)objectives of the research is used quantitative positivistic approach research method, survey method, statistically correlated with structural equation model step. Research measurement model using Confirmatory FactorAnalysis. (Ruzzier et al., 2007)(Alraja et al., 2020). To the collect primary data, sampling design to provides a methodologys for the appropriate respondent sample size. The research process begins with the process of managing permits to collect data (Beskow \& Dean, 2008)in PAUD and DIKMAS Central Java and collect informed consent from non-formal PAUD Educators who are participants. Data collection is done through google form(Chandler \& Tsai, 2001) fills five scales, namely predisposition factor scale, leadership, trainingclimate, cost, infrastructure, training planning, training implementation, and scale of use of etraining and training results. The collected answers are then tabulated and analyzed. The (Blunch, 2017)involvement of Non-formal PAUD educators in becoming participants is voluntary. Therefore, before the data collection is carried out, non-formal PAUD educators are first asked to fill out an approval form to become a participant in this research. After the participants have finished filling the entire scale item, they will get a package of souvenirs for their willingness to fill the entire scale item.

\section{Participants}

The population of this research is Non-formal PAUD Educators who participated in e-training-based training in Central Java at PAUD and DIKMAS Institutions in Central Java. The number of PAUD educators who have participated in the training is 2584. Criteria for PAUD educators who are determined as samples must follow the training program and obtain certificates issued by PAUD and DIKMAS Central Java. The sample technique of the study used simple random sampling, the amount is set with the formula Slovin with an error rate of 5 percent, a number of 183 fill qoesioner validly. 


\section{Measure}

Primary data collection techniques with questionnaires or questionnaires and documentation. Shape Scale Level of Questionnaire Instrument (1 - 4) Modification of Likert Scale. Questionnaire as an instrument of measurement of exogenous and endogenous variables in this study measured its validity and reliabelity in order to provide measuring results in accordance with the objectives of measurement or research objectives. Measurement of instrument validity with Pearson Product Moment formula. Instruments are valid if $r$ calculate $>r$ table, and invalid if $r$ calculates $<r$ table, with significance of 0.05 . Instrument measurement using the Alpha Cronbach coefficient method. The amount of the instrument's reliability coefficient is between $0.00-1.00$, which can be accepted as a reliable instrument if it meets a minimum positive coefficient of 0.6 .

\section{Data Analysis and Result}

Data analysis was carried out, namely Structural Equation Modeling (SEM) analysis. All data for analysis processes are carried out using the AMOS version 24 software. After two-step techniques, we assess the entire measurement the model for six latent variables in a single confirmation factor analysis procedure (CFA). Measurement items for each latent variable with the descriptive statistics and standard CFA loading, are presented in Table I. As shown in Table II, with the exception of the standard estimate of each item from previous experience and the need for cognition, respectively 0.52 and 0.58 , respectively for with all other items greater than 0.6. As a result, composite reliability (CR) and average extracted variants (AVE) are calculated from CFA loads. With the exception of AVE for cognition needs (0.41), other latent variables are above the 0.50 limit criteria. These results are not surprising because other studies have reported low CFA loads for the needs of cognis items. Additionally, the CR value for all latent variables is above the 0.7 limit criteria. Thus, the validity of convergents is indicated for all latent variables.(Arbuckle, 2016)(Anderson \& Gerbing, 1988)(Claes Fornell and David F. Larcker, 1981)(Cacioppo, J. \& Feng Kao, 1984)(Bors et al., 2006)(Hair et al., 2010)(Ghozali, 2017)

Discriminant validity is shown when variance with correlation between latent variable pairs is lower than AVE for each variable. The AVE value for each latent variable is printed on a diagonal, with the shared variance printed from diagonal (Table III). Latent variables indicate a high degree of discriminant validity because the AVE for each variable is greater than the corresponding shared variant.(Cheung \& Rensvold, 2002)

Table 1. Confirmatory Factor Analysis Results

\begin{tabular}{|c|c|c|c|c|c|c|}
\hline Variable & Indicators & $\begin{array}{c}\text { Loading } \\
\text { Standards }\end{array}$ & $\begin{array}{l}\text { Standard } \\
\text { Loading }^{2}\end{array}$ & $\begin{array}{c}\text { 1- } \\
\text { Standard } \\
\text { Loading }^{2}\end{array}$ & $\begin{array}{l}\text { Construct } \\
\text { Reliability }\end{array}$ & Ket \\
\hline \multirow{5}{*}{$\begin{array}{l}\text { Predisposing } \\
\text { factor }\end{array}$} & fp1 & 0.664 & 0.440896 & 0.559104 & \multirow[t]{5}{*}{0.81080755} & \multirow[t]{5}{*}{ Reliabel } \\
\hline & fp2 & 0.659 & 0.434281 & 0.565719 & & \\
\hline & fp3 & 0.668 & 0.446224 & 0.553776 & & \\
\hline & fp4 & 0.744 & 0.553536 & 0.446464 & & \\
\hline & fp5 & 0.66 & 0.4356 & 0.5644 & & \\
\hline \multirow[t]{4}{*}{ Leadership } & kp1 & 0.7 & 0.49 & 0.51 & \multirow[t]{4}{*}{0.754482798} & \multirow[t]{4}{*}{ Reliabel } \\
\hline & kp2 & 0.61 & 0.3721 & 0.6279 & & \\
\hline & kp3 & 0.782 & 0.611524 & 0.388476 & & \\
\hline & kp4 & 0.533 & 0.284089 & 0.715911 & & \\
\hline \multirow[t]{2}{*}{ Climate } & ip1 & 0.582 & 0.338724 & 0.661276 & \multirow[t]{4}{*}{0.759669933} & \multirow[t]{4}{*}{ Reliabel } \\
\hline & ip2 & 0.745 & 0.555025 & 0.444975 & & \\
\hline \multirow[t]{2}{*}{ Training } & ip3 & 0.756 & 0.571536 & 0.428464 & & \\
\hline & ip4 & 0.564 & 0.318096 & 0.681904 & & \\
\hline \multirow[t]{4}{*}{ Cost } & b1 & 0.638 & 0.407044 & 0.592956 & \multirow[t]{4}{*}{0.709246717} & \multirow[t]{4}{*}{ Reliabel } \\
\hline & B2 & 0.725 & 0.525625 & 0.474375 & & \\
\hline & b3 & 0.587 & 0.344569 & 0.655431 & & \\
\hline & b4 & 0.504 & 0.254016 & 0.745984 & & \\
\hline \multirow[t]{2}{*}{ Means } & sp1 & 0.703 & 0.494209 & 0.505791 & \multirow[t]{4}{*}{0.710518549} & \multirow[t]{4}{*}{ Reliabel } \\
\hline & sp2 & 0.619 & 0.383161 & 0.616839 & & \\
\hline \multirow{2}{*}{ Infrastructure } & sp3 & 0.578 & 0.334084 & 0.665916 & & \\
\hline & sp4 & 0.563 & 0.316969 & 0.683031 & & \\
\hline \multirow[t]{2}{*}{ Planning } & pp1 & 0.538 & 0.289444 & 0.710556 & \multirow[t]{2}{*}{0.745271957} & \multirow[t]{2}{*}{ Reliabel } \\
\hline & pp2 & 0.697 & 0.485809 & 0.514191 & & \\
\hline
\end{tabular}




\begin{tabular}{|c|c|c|c|c|c|c|}
\hline \multirow[t]{2}{*}{ Training } & pp3 & 0.784 & 0.614656 & 0.385344 & \multirow{5}{*}{0.788313857} & \multirow{4}{*}{ Reliabel } \\
\hline & pp4 & 0.568 & 0.322624 & 0.677376 & & \\
\hline \multirow[t]{2}{*}{ Implementation } & pl1 & 0.629 & 0.395641 & 0.604359 & & \\
\hline & $\mathrm{pl} 2$ & 0.669 & 0.447561 & 0.552439 & & \\
\hline \multirow[t]{3}{*}{ Training } & $\mathrm{pl} 3$ & 0.599 & 0.358801 & 0.641199 & & \\
\hline & pl4 & 0.646 & 0.417316 & 0.582684 & & \\
\hline & pl5 & 0.721 & 0.519841 & 0.480159 & & \\
\hline \multirow[t]{8}{*}{ E-Training } & hp1 & 0.665 & 0.442225 & 0.557775 & 0.837432566 & Reliabel \\
\hline & hp2 & 0.599 & 0.358801 & 0.641199 & & \\
\hline & hp3 & 0.595 & 0.354025 & 0.645975 & & \\
\hline & hp4 & 0.699 & 0.488601 & 0.511399 & & \\
\hline & hp5 & 0.558 & 0.311364 & 0.688636 & & \\
\hline & hp6 & 0.704 & 0.495616 & 0.504384 & & \\
\hline & et1 & 0.593 & 0.351649 & 0.648351 & & \\
\hline & et2 & 0.587 & 0.344569 & 0.655431 & & \\
\hline \multirow[t]{6}{*}{ Training Results } & et3 & 0.662 & 0.438244 & 0.561756 & 0.757232586 & Reliabel \\
\hline & et 4 & 0.549 & 0.301401 & 0.698599 & & \\
\hline & et5 & 0.614 & 0.376996 & 0.623004 & & \\
\hline & et6 & 0.554 & 0.306916 & 0.693084 & & \\
\hline & et7 & 0.502 & 0.252004 & 0.747996 & & \\
\hline & et8 & 0.623 & 0.388129 & 0.611871 & & \\
\hline
\end{tabular}

SEM analysis was conducted to testing the model proposed in the research as shown in figure 2 hypothesis. Some of the criteria used to assess whether the model is fit or not are the results of the square kai test (s2), the comparison of kai squares with degrees offreedom or $\mathrm{db}(12 / \mathrm{db})$, Comparative Fit Index (CFI), Root Mean Square Error Approximation (RMSEA), and Standardized Root Mean Square Residual (SRMR). Models are acceptable if the value(Bagozzi \& Yi, 2012)(Hu \& Bentler, 1999) of 2/db is not more than 3, CFI above 0.90 or more is expected to reach 0.95 or more, RMSEA is less than 0.06 , and SRMR is less than 0.09. (Hu \& Bentler, 1999). Therefore, the model will becategorized as appropriated and feasible to using, so that explanation can be done for the further explanation. 


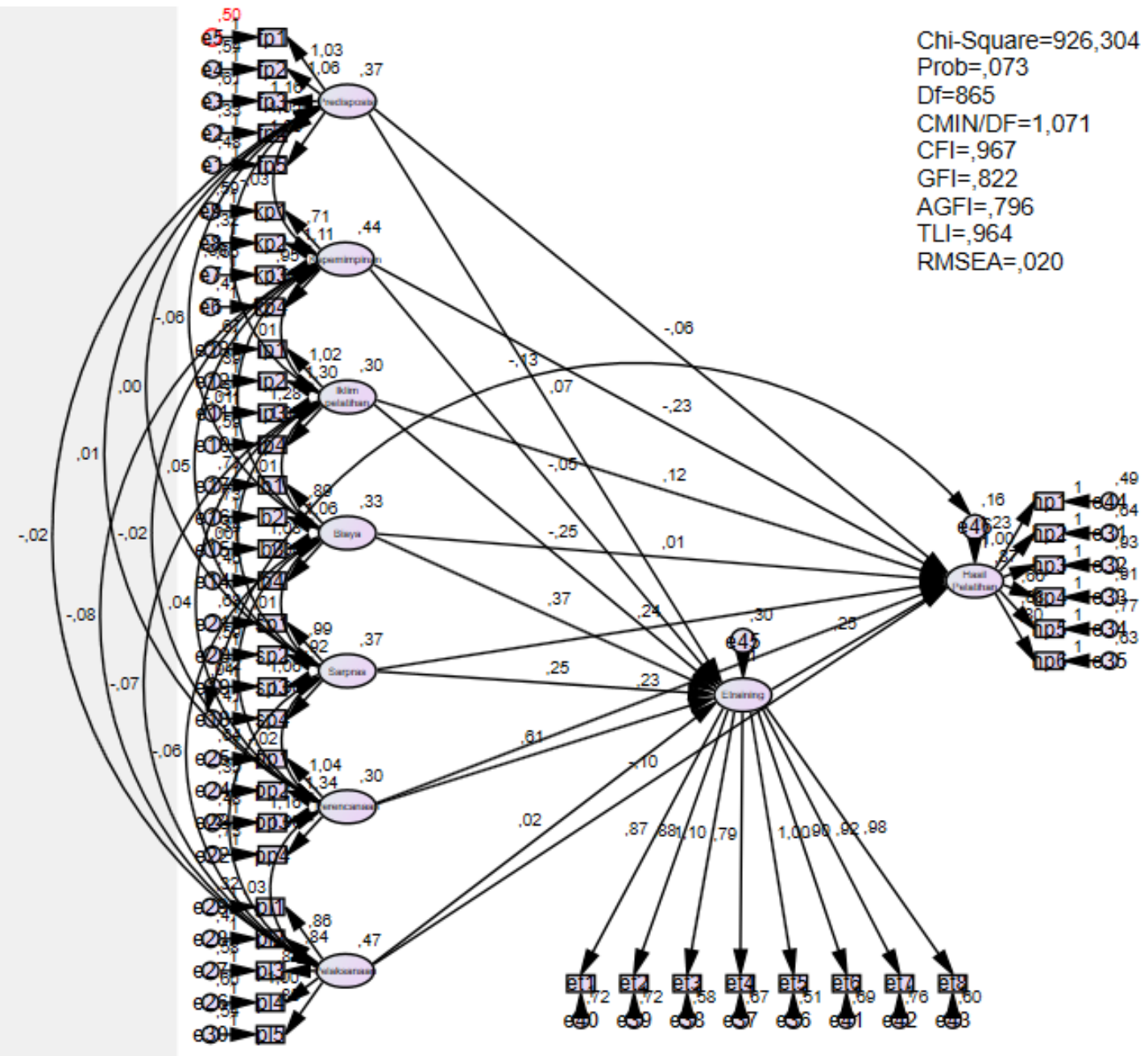

Figure 1. Path Analysis of SEM Analysis Result Source: Researcher's private documentation

Analsis path analysis of SEM model is a stage that is done after the analysis on the prerequisites of the test has been met. Analysis of data processing results in the whole or full sem model is done with the goodness of test conformity and statistical test. The follow for a presentation from the results of overall analysis full model model in the form of images.

Table 2. The Test Result of Goodness of Fit Overall Models

\begin{tabular}{lccc}
\multicolumn{1}{c}{ Goodness of Fit Index } & Cut-off Value & Results & Model Evaluation \\
\hline $\mathrm{X}^{2}$ Chi-Square Statistics & $\mathrm{df}, \alpha \leq 948.04$ & 926,30 & Good \\
Probability & $\geq 0.05$ & 0,073 & Good \\
CMIN/DF & $\leq 2.00$ & 1,071 & Good \\
Gfi & $\geq 0.90$ & 0,822 & Marginal \\
AGFI & $\geq 0.90$ & 0,796 & Marginal \\
TLI & $\geq 0.90$ & 0,964 & Good \\
Cfi & $\geq 0.90$ & 0,967 & Good \\
RMSEA & $\leq 0.08$ & 0,020 & Good \\
\hline
\end{tabular}

Source: Researcher's private documentation.

\section{Analysis}

Hypothesis testing is a stage that must be taken after SEM testing to meet the hypothesis for proposed in this study. Testing for all hypotheses is done by the look at the value of the critical ratio (C.R) of the casual relationship from the SEM processing results as presented in the following table. 
Table 3. Standardized Structural Estimates of the Structural Model (Direct Relationship)

\begin{tabular}{|c|c|c|c|c|c|c|c|}
\hline & & & Estimate & S.E. & C.r. & $\mathbf{Q}$ & Label \\
\hline Etraining & $<--$ & Predisposing & ,067 & 101 & 671 & ,503 & par_43 \\
\hline Etraining & $<---$ & Leadership &,- 048 & ,091 &,- 526 & ,599 & par_44 \\
\hline Etraining & $<---$ & process_training &,- 248 & 119 & $-2,091$ & ,037 & par_45 \\
\hline Etraining & $<---$ & Cost & 371 & 120 & 3,098 & ,002 & par_46 \\
\hline Etraining & $<---$ & Fasilitating & 249 & 107 & 2,335 & ,020 & par_47 \\
\hline Etraining & $<---$ & Planning & 607 & 140 & 4,337 & $* * *$ & par_48 \\
\hline Etraining & $<---$ & Implementation & ,017 & ,089 & ,194 & 846 & par_49 \\
\hline Training Results & $<---$ & Predisposing &,- 056 & ,084 &,- 660 & ,509 & par_36 \\
\hline Training Results & $<---$ & Leadership &,- 231 & ,085 & $-2,725$ & ,006 & par_37 \\
\hline Training Results & $<---$ & process_training & 123 & 102 & 1,207 & ,227 & par_38 \\
\hline Training Results & $<---$ & Cost & ,007 & 100 & ,072 & 943 & par_39 \\
\hline Training Results & $<---$ & Fasilitating & ,240 & 109 & 2,200 & ,028 & par_40 \\
\hline Training Results & $<---$ & Planning & ,227 & ,116 & 1,947 & ,052 & par_41 \\
\hline Training Results & $<---$ & Implementation &,- 097 & ,075 & $-1,305$ & ,192 & par_42 \\
\hline Training Results & $<---$ & Etraining & ,245 & ,101 & 2,425 & ,015 & par_50 \\
\hline
\end{tabular}

Source: Researcher's private documentation

The estimation parameter of the predisposition factor effect test on the training result shows a C.R value of -0.667 with a probability $>0.05$. So, it can be concluded that the variable predisposition factor has no significant effect on the training results.

The estimation parameter on the leadership influence test on the training result shows a C.R value of 2,789 with a probability of $<0.05$. So, it can be concluded that leadership variables have a positive and significant effect on the results of training.

The estimation parameter on the training climate impact test on the training result shows a C.R value of 0.235 with a probability $>0.05$. So, it can be concluded that the training climate variables have a positive and insignificant effect on the training results.

The estimation parameter on the cost effect test on the training result shows a C.R value of 0.072 with a probability of $>0.05$. So, it can be concluded that variable costs have a positive and insignificant effect on the results of training.

The estimation parameter on the infrastructure effect test on the training result shows a C.R value of 2,251 with a probability of $<0.05$. So, it can be concluded that the variables of facilities and infrastructure have a positive and significant effect on the results of training.

The estimation parameter on the training planning effect test on training results shows a C.R value of 1,933 with a probability of $<0.05$. So, it can be concluded that the training planning variables have a positive and significant effect on the training results.

The estimation parameter on the test effect of training implementation on training results shows a C.R value of -1.315 with a probability $>0.05$. So, it can be concluded that the variables of training implementation have a negative and insignificant effect on the training results.

The estimation parameter of the predisposed factor effect test on the use of e-training indicates the value of C.R. of 0.688 with a probability value of 0.504 then the probability value $>0.05$. So, it can be concluded that the variable predisposition factor indirectly affects the positive and insignificant to the results of training through the use of e-training.

The estimated parameter of the leadership influence test on the use of e-training shows the C.R value of -0.527 with a probability value of 0.598 then the probability value $>0.05$. So, it can be concluded that leadership variables indirectly do not affect to the results of training through the use of e-training.

The estimation parameter for testing the effect of the training climate on the use of e-training shows a C.R value of 2.075 with a probability value of 0.038 then the probability value $<0.05$. So, it can be concluded that the training climate variables indirectly have a positive and the a significant to effect on the results of training through the use of e-training.

The estimation parameter on the cost effect test on the use of e-training shows the value C.R of 3.091 with a probability value of 0.002 then the probability value $<0.05$. So, it can be concluded that variable costs indirectly have a positive and significant effect on the results of training through the use of e-training.

The estimation parameter on the testing of the influence of facilities and infrastructure on the use of e-training shows a C.R value of 2.338 with a probability value of 0.019 then the probability value $<0.05$. 
So, it can be concluded that the variables of facilities and infrastructure indirectly have a positive and significant effect on the results of training through the use of e-training.

The estimation parameter on the test of the effect of training planning on the use of e-training shows a C.R value of 4.278 with a probability value of 0.001 then the probability value $<0.05$. So, it can be concluded that the variables of training planning indirectly have a positive and significant effect on the results of training through the use of e-training.

The estimation parameter on the test effect of training implementation on the use of e-training shows the value C.R of 0.194 with a probability value of 0.846 then the probability value $>0.05$. So, it can be concluded that the variables of training implementation indirectly have a positive and insignificant effect on the results of training through the use of e-training.

The estimation parameter on the e-training effect test on the training result shows a C.R value of 2.477 with a probability of $<0.05$. So, it can be concluded that e-training variables have a positive and significant effect on the results of training.

\section{Discussion}

Results of this study are in line with various studies that try to identify critical issues of training results described by (Jusuf Irianto, 2007) namely: (a) analysis of training needs, which does not related to the business strategy plan, (b) technical implementation of training programs, especially on the use of training methods that are not in a just in time pattern, does not encourage the follow-up of trainees applying the results of training in workunits, (c) designingtraining that does not pay attention to the suitability ofthe training material (content)with individuals orworkunits, (d) static delivery methods, only one classroom delivery method (e) the impact of training for individuals and organizations, is not systematically measured, (f) supporting facilities that help trainees apply the learned competencies are not given periodically.

The research (Pradiani, 2018) states that training materials on educator training are seen as the most effective and efficient promotional media to increase sales volume significantly. Research conducted by (Rasyad et al., 2019) simultaneously, instructor quality, facility completeness, module availability, quality evaluation, and material accuracy can also improve the quality of this exogenous variable improve to the results of the training, as measuring by the quality of their teaching for education. The results of research on determining the effectiveness of the training model of research results in Germany by (Tonhäuser \& Büker, 2016) distinguished 3 factors, namely (a) factors from the organization, (b) learning field factors and (c) individual factors. Organizational factors show social support, and organizational structural conditions at work. At the level of analysis of the field of learning, focus is a training design, such as the practical relevance of the content and design of methodological methodologies. At the individual level, participants are the focus of observation, the effect of determining further vocational training participants, such as motivation, will, and personal factors, as well as cognitive abilities, in the training transfer examined. It further concludes that the most important determining factors in the transfer of training are organizational characteristics as a work environment, specific learning characteristics, and participant characteristics at the individual level.

\section{Conclusion}

Predisposition factors indirectly have a positive and insignificant effect on the results of training through the use of e-training. Indirect leadership has no effect on the results of training through the use of e-training. The training climate indirectly has a positive and significant influence on the results of training through the use of e-training. Indirectly, the cost has a positive and insignificant effect on the results of training through the use of e-training. Facilities and infrastructure indirectly have a positive and significant influence on training results through the use of e-training.

Training planning indirectly has a positive and significant influence on the results of training through the use of e-training. Training implementation indirectly has a positive and insignificant effect on the results of training through the use of e-training. The electronic training variable directly affects the positive, significant to impact on the results of the training. In order for the implementation of training through electronic training in more complete follow-up in the form of follow-up training by taking into account the mastery of the mastery of professional competencies from the trainees. E-training models can be developed in similar training with modification based on the needs of trainees.

\section{References}

Alraja, M. N., Khan, S. F., Khashab, B., \& Aldaas, R. (2020). Does Facebook Commerce Enhance SMEs Performance? A Structural Equation Analysis of Omani SMEs. SAGE Open, 10(1). https://doi.org/10.1177/2158244019900186 
Anderson, J. C., \& Gerbing, D. W. (1988). Structural Equation Modeling in Practice: A Review and Recommended Two-Step Approach. Psychological Bulletin, 103(3), 411-423. https://doi.org/10.1037/0033-2909.103.3.411

Arbuckle, J. L. (2016). Amos 24 User's Guide. Amos 24 User's Guide.

Bagozzi, R. P., \& Yi, Y. (2012). Specification, evaluation, and interpretation of structural equation models. Journal of the Academy of Marketing Science, 40(1), 8-34. https://doi.org/10.1007/s11747-011$\underline{0278-x}$

Beskow, L. M., \& Dean, E. (2008). Informed consent for biorepositories: Assessing prospective participants' understanding and opinions. Cancer Epidemiology Biomarkers and Prevention, 17(6), 1440-1451. https://doi.org/10.1158/1055-9965.EPI-08-0086

Blunch, N. J. (2017). Structural Equation Modeling with AMOS. In Introduction to Structural Equation Modeling using IBM SPSS Statistics and AMOS. https://doi.org/10.4135/9781526402257.n4

Bors, D. A., Vigneau, F., \& Lalande, F. (2006). Measuring the need for cognition: Item polarity, dimensionality, and the relation with ability. Personality and Individual Differences, 40(4), 819-828. https://doi.org/10.1016/j.paid.2005.09.007

Cacioppo, J. T., Petty, R. E., \& Feng Kao, C. (1984). The Efficient Assessment of Need for Cognition. Journal of Personality Assessment, 48(3), 306-307. https://doi.org/10.21074/kjlcap.2007.8.1.127

Chandler, C. R., \& Tsai, Y. M. (2001). Social factors influencing immigration attitudes: An analysis of data from the General Social Survey. Social Science Journal, 38(2), 177-188. https://doi.org/10.1016/S0362-3319(01)00106-9

Cheung, G. W., \& Rensvold, R. B. (2002). Evaluating Goodness-of-Fit Indexes for Testing Measurement $\begin{array}{llll}\text { Invariance. } & \text { Structural } & \text { Equation } & \text { Modeling, }\end{array}$ https://doi.org/10.1207/S15328007SEM0902

Claes Fornell and David F. Larcker. (1981). Evaluating Structural Equation Models with Unobservable Variables and Measurement Error. Journal of Marketing Research, 18(1), 39-50. https://doi.org/10.20546/ijcrar.2016.409.006

Creswell, J. (2013). Qualitative, quantitative, and mixed methods approaches. In Research design.

Djibu, R., Chairul, S. M., \& Umanailo, B. (2019). Development Of Andragogical Learning Model To Improve Life Skill For Teenagers Who Drop Out Of School In Gorontalo City. INTERNATIONAL JOURNAL OF SCIENTIFIC \& TECHNOLOGY RESEARCH, 8(11). www.ijstr.org

Ghozali, I. (2017). Model Persamaan Struktural. Konsep dan Aplikasi Dengan Program AMOS 24.0. Update Bayesian SEM. In Model Persamaan Struktural. Konsep dan Aplikasi Dengan Program AMOS 24. Update Bayesian SEM. https://doi.org/10.1016/i.ando.2009.02.007

Hair, J., Black, W., Babin, B., \& Anderson, R. (2010). Multivariate Data Analysis: A Global Perspective. In Multivariate Data Analysis: A Global Perspective.

Hu, L. T., \& Bentler, P. M. (1999). Cutoff criteria for fit indexes in covariance structure analysis: Conventional criteria versus new alternatives. Structural Equation Modeling, 6(1), 1-55. https://doi.org/10.1080/10705519909540118

Jusuf Irianto. (2007). Prinsip Prinsip Dasar Manajemen Pelatihan.

Pradiani, T. (2018). Pengaruh Sistem Pemasaran Digital Marketing Terhadap Peningkatan Volume Penjualan Hasil Industri Rumahan. Jurnal Ilmiah Bisnis Dan Ekonomi Asia, 11(2), 46-53. https://doi.org/10.32812/jibeka.v11i2.45

Rasyad, A., Wiyono, B. B., Zulkarnain, \& Sucipto. (2019). The determinant factors that influence results of gradual training of early childhood education teachers based on the program evaluation in Indonesia. Cogent Education, 6(1). https://doi.org/10.1080/2331186X.2019.1702840

Republik Indonesia. (2005). Undang-undang Nomor 14 Tahun 2005 tentang Guru dan Dosen. Sekretariat Negara.

Robert Thornberg. (2012). Informed grounded theory. Scandinavian Journal of Educational Research, 56(3), 243-259.

Ruzzier, M., Antoncic, B., Hisrich, R. D., \& Konecnik, M. (2007). Human capital and SME internationalization: A structural equation modeling study. Canadian Journal of Administrative Sciences, 24(1), 15-29. https://doi.org/10.1002/cjas.3

Setyowati, A. (2010). Upaya Meningkatkan Kecerdasan Verbal Linguistik Anak Melalui Membaca. Universitas Muhamadiyah Surakarta.

Shofwan, I., Tri, J., Raharjo, A., Rifai, R. C., Fakhruddin, F., Sutarto, J., Utsman, U., Arbarini, M., Suminar, T., Mulyono, S. E., Kisworo, B., Malik, A., Yusuf, A., Ilyas, I., Desmawati, L., Chairul, M., \& Umanailo, B. (2019). Non-Formal Learning Strategy Based On Tahfidz And Character In The Primary School. INTERNATIONAL JOURNAL OF SCIENTIFIC \& TECHNOLOGY RESEARCH, 8(10). www.ijstr.org. 
Thakur, R., \& Natale, A. (2009). Peraturan Kementrian Pendidikan Nasional Republik Indonesia No. 58 Tahun 2009 Tentang Standar Pendidikan Anak Usia Dini. Cardiology Clinics.

Tonhäuser, C., \& Büker, L. (2016). Determinants of transfer of training: A comprehensive literature review. International Journal for Research in Vocational Education and Training, 3(2), 127-165. https://doi.org/10.13152/IJRVET.3.2.4

Weston, R., \& Gore, P. A. (2006). A Brief Guide to Structural Equation Modeling. The Counseling Psychologist, 34(5), 719-751. https://doi.org/10.1177/0011000006286345

Widodo, H. (2016). Potret Pendidikan Di Indonesia Dan Kesiapannya Dalam Menghadapi Masyarakat Ekonomi Asia (Mea). Cendekia: Journal of Education and Society, 13(2), 293. https://doi.org/10.21154/cendekia.v13i2.250 